\title{
Gas Chromatographic Determination of Phenol in Fish Tissues as a Phenyl Acetate Derivative Following Solvent Extraction of Acidified Samples
}

\author{
H. Kim ${ }^{1 *}$, Y. Kim ${ }^{2}$, S. Park ${ }^{2}$,J. Lee ${ }^{3}$ and J. Choi ${ }^{4}$ \\ 'School of Natural Resources and Environmental Science, Kangwon National University, \\ Chuncheon, Kangwon-do 24341, Republic of Korea \\ ${ }^{2}$ Department of Environmental Science, Kangwon National University, \\ Chuncheon, Kangwon-do 24341, Republic of Korea \\ ${ }^{3}$ Natural and Human Co., Ltd., Bugwon-ro, Wonju, Kangwon-do 26424, Republic of Korea \\ ${ }^{4}$ Institute of Environmental Research, Kangwon National University, Chuncheon, Kangwon-do 24341, Republic of Korea
}

Received: 13 August 2018; accepted: 10 September 2018

\begin{abstract}
This study aimed to develop a chromatographic method to quantitatively determine phenol in fish tissues. This method involves solvent extraction of acidified samples, followed by derivatization to phenyl acetate and analysis with gas chromatography coupled with mass spectrometry (GC-MS). Phenol in a representative tissue sample (belly, gill, or renal tubules), which was homogenized with $2 \mathrm{~N}$ sulfuric acid, was extracted with ethyl acetate and derivatized to phenyl acetate using acetic anhydride and $\mathrm{K}_{2} \mathrm{CO}_{3}$ in water. An $n$-butyl acetate extract was injected into the GC-MS. The linearity $\left(r^{2}\right)$ of the calibration curve was greater than 0.996 . The analytical repeatability, which is expressed as the relative standard deviation, was less than $6.14 \%$, and the recovery was greater than $96.3 \%$. The method detection limit and the limit of quantitation were $8.0 \mu \mathrm{g} / \mathrm{kg}$ and $26 \mu \mathrm{g} / \mathrm{kg}$, respectively. The proposed method is also applicable to the analysis of other biological tissues for phenol and its analogs, such as pentachlorophenol.
\end{abstract}

Keywords: acetylation, fish, GC-MS, phenol, solvent extraction

\section{Introduction}

Phenol is an organic compound of an anthropogenic origin, which is widely used in phenolic resins and plywood adhesives among others, and is also found in petroleum products, such as coal tar and creosote [1]. Additionally, phenol occurs naturally in the environment, where it is formed via the degradation of organic matter, such as benzene. Benzene is commonly found in the environment, including surface water [2].

To date, no toxicological studies have reported phenol to be carcinogenic for humans. However, it may cause acute toxicities, such as cardiovascular diseases or gastrointestinal disorders, which can lead to death in the event of a high dose $[1,3]$. Depending on the administered dosage, fish suffer behavioral, respiratory, and lethal effects $[4,5]$. Therefore, the concentration of phenol in fish and in the water needs to be measured in order to protect fish and humans from any possible harmful effects.

Most studies on the quantitative determination of phenol are commonly conducted on water, usually using gas chromatography (GC) mostly, following derivatization to more lipophilic compounds, such as phenyl acetate [6-10]. However, the analytical methods for biological tissues, including fish, are highly limited. The United States Environmental Protection Agency (EPA) monitored 268 toxic chemicals, including phenol, in tissues of fish from lakes and reservoirs in the USA [11] using the EPA Method 1625C [12]. This method was essentially developed for analyzing semivolatile organic compounds in water, soil, and municipal sludge, not for biological samples. This method employed ultrasonication with dichloro-

* Author for correspondence: kimh@kangwon.ac.kr methane (DCM) for extraction after acidifying samples to a $\mathrm{pH}$ of less than 2, cleanup using gel permeation chromatography, and gas chromatography coupled with mass spectrometry (GC-MS) analysis without derivatization. A similar procedure was applied to analyze foods, such as corn, mackerel, and rice, and the limit of quantitation (LOQ) was estimated as 100 or $300 \mu \mathrm{g} / \mathrm{kg}$ [13].

The aim of this study was to lower the limit of quantification and to reduce the analysis time by employing acidified homogenization, centrifugation, solvent extraction, and derivatization.

\section{Experimental}

Chemicals. Phenol $(5000 \mu \mathrm{g} / \mathrm{mL})$ was purchased from Supelco (Bellefonte, PA, USA), and $0.2 \mathrm{~mL}$ of the phenol solution was diluted with methanol to prepare $100 \mathrm{~mL}$ of a $1 \mathrm{mg} / \mathrm{L}$ standard solution. Further, $o$-cresol, potassium carbonate, and acetic anhydride were obtained from SigmaAldrich (St. Louis, MO, USA). Sulfuric acid and sodium chloride were purchased from Junsei Chemical (Kyoto, Japan) and Showa (Tokyo, Japan), respectively. DCM, ethyl acetate, and methanol were purchased from Tedia (Fairfield, $\mathrm{OH}$, USA). $n$-Butyl acetate and sodium sulfate were obtained from Daejung (Siheung, Republic of Korea).

Sample Preparation. One gram of each fish tissue sample (belly, gill, and renal tubules) was placed in a $40-\mathrm{mL}$ glass vial, into which $2 \mu \mathrm{L}$ of $o$-cresol $(207.2 \mathrm{mg} / \mathrm{L})$ as a surrogate to compensate for the variations in matrix effect and method performance between samples and $5 \mathrm{~mL}$ of $2 \mathrm{~N} \mathrm{H}_{2} \mathrm{SO}_{4}$ were added. The mixture was homogenized using a homogenizer (SHG-15A; Scilab, Seoul, Republic of Korea) and then

This is an open-access article distributed under the terms of the Creative Commons Attribution-NonCommercial 4.0 International License (https://creativecommons.org/licenses/by-nc/4.0/), which permits unrestricted use, distribution, and reproduction in any medium for non-commercial purposes, provided the original author and source are credited, a link to the CC License is provided, and changes - if any - are indicated. 


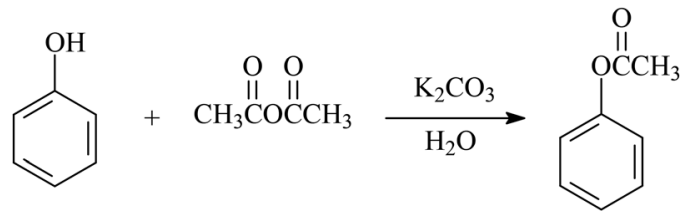

Figure 1. Derivatization reaction of phenol to phenyl acetate

ultrasonicated (POWERSONIC 510; Hwashin Instrument, Seoul, Republic of Korea) for $10 \mathrm{~min}$. The homogenate was transferred into a $15-\mathrm{mL}$ glass centrifuge tube and centrifuged at $3600 \mathrm{rpm}$ for $20 \mathrm{~min}$ (Centrifuge HA-12; Hanil Science, Daejeon, Republic of Korea). The supernatant was transferred into a $40-\mathrm{mL}$ glass vial, into which $10 \mathrm{~mL}$ of ethyl acetate was added, and the resulting mixture was shaken for $15 \mathrm{~min}$ using a rotary shaker (MaxiMix III Type 65800; Barnstead Thermolyne, Dubuque, USA) to extract phenol. The upper ethyl acetate layer was transferred into a $40-\mathrm{mL}$ glass vial. This liquid-liquid extraction operation was repeated once more. The extract was dried over ca. $2 \mathrm{~g}$ of sodium sulfate. The filtrate was concentrated to ca. $2-3 \mathrm{~mL}$ at $40{ }^{\circ} \mathrm{C}$ using a rotary evaporator (HS 2000, Hahn Shin S\&T, Gimpo, Korea). The concentrate was transferred to a $15-\mathrm{mL}$ glass centrifuge tube and dried using a mild nitrogen stream. Phenol and $o$-cresol in the tube were derivatized to phenyl acetate by adding $100 \mu \mathrm{L}$ of acetic anhydride and $500 \mu \mathrm{L}$ of $5 \% \mathrm{~K}_{2} \mathrm{CO}_{3}$ into the centrifuge tube containing $1 \mathrm{~mL}$ of water (Figure 1). The mixture was vortex-shaken for $20 \mathrm{~s}$ and left at room temperature for $10 \mathrm{~min}$, and then $0.5 \mathrm{mg}$ of $\mathrm{NaCl}$ and $1 \mathrm{~mL}$ of $n$-butyl acetate were added to the tube, and the mixture was vortex-shaken again for $1 \mathrm{~min}$. Approximately one-half of the 1-mL upper organic layer was transferred into a 2-mL glass vial, and $1 \mu \mathrm{L}$ was injected into the GC-MS apparatus.

Instrumental Conditions. A 7890A gas chromatograph with a 5975C mass spectrometer (Agilent Technologies, Santa Clara, CA, USA) was used for instrumental analyses (Table 1). A DB-WAX capillary column $(30 \mathrm{~m} \times 0.25 \mathrm{~mm} \times 0.25 \mu \mathrm{m}$; Agilent Technologies) was used as an analytical column. One microliter of each sample in the vial was injected into the GC-MS apparatus in splitless mode with a 7693A autosampler (Agilent Technologies). The inlet temperature was maintained at $240{ }^{\circ} \mathrm{C}$. The carrier gas was helium, flowing at a rate of $1 \mathrm{~mL} / \mathrm{min}$. The gas chromatograph oven temperature was programmed as follows: the temperature was initially maintained at $40{ }^{\circ} \mathrm{C}$ for $3 \mathrm{~min}$, then elevated to $150{ }^{\circ} \mathrm{C}$ at $10{ }^{\circ} \mathrm{C} / \mathrm{min}$ and thereafter to $230{ }^{\circ} \mathrm{C}$ at $25{ }^{\circ} \mathrm{C} / \mathrm{min}$, and finally maintained at $230{ }^{\circ} \mathrm{C}$ for $20 \mathrm{~min}$. The mass spectrometer was operated in the electron impact mode for ionization and in the selected ion monitoring mode for quantitation. Fragment ions $(\mathrm{m} / \mathrm{z})$ of 66 and 94 were selected for the quantitative determination of phenyl acetate, whereas those of 107 and 108 were selected for $o$-cresyl acetate.
Method Validation. The developed method was validated using the belly tissue of dace. Calibration curves were drawn for 2 concentration ranges: $10-100 \mu \mathrm{g} / \mathrm{kg}$ (spiking $10-100 \mu \mathrm{L}$ of the $1 \mathrm{mg} / \mathrm{L}$ standard solution) and 100-600 $\mu \mathrm{g} / \mathrm{kg}$ (spiking $100-600 \mu \mathrm{L}$ of the $1 \mathrm{mg} / \mathrm{L}$ standard solution). The method detection limit (MDL) was estimated according to the EPA procedure [14], and the LOQ was estimated by multiplying the MDL by 3.18. The analytical accuracy and precision were evaluated in terms of recovery and repeatability, expressed as the relative standard deviation (RSD, \%), respectively, for triplicate measurements for 10 and $100 \mu \mathrm{g} / \mathrm{kg}$.

Application to Fish Tissues. Fish were captured from the Nakpung and Jusu streams in Gangneung, Kangwon-do, and the Jeoncheon stream in Donghae, Kangwon-do, Republic of Korea, using a fishing net at each stream site in August and November 2015. The three major species in these streams were dace (Tribolodon hakonensis), striped mullet (Mugil cephalus), and crucian carp (Carassius carassius). Composite samples of the fish belly, gill, and renal tubules were obtained immediately after capturing the fish. Each sample was transported to the laboratory in a portable freezer containing dry ice and then stored at $-30{ }^{\circ} \mathrm{C}$ until analysis within 30 days.

\section{Results and Discussion}

Optimization for the Extraction of Phenol and Phenyl Acetate. Ethyl acetate was reported to be an efficient solvent for the extraction of phenol from water [6]. In this study, it also proved to be an appropriate solvent for extracting phenol from fish tissues. Since the average peak area count for $n$-butyl acetate was ca. 1.6 times higher than those for both DCM and ethyl acetate, $n$-butyl acetate was chosen to be the most suitable solvent for extracting phenyl acetate from the aqueous reaction mixture containing a small amount of sodium chloride (Figure 2).

Chromatograms. Figure 3 shows the chromatograms for a standard $100 \mu \mathrm{g} / \mathrm{kg}$ and a belly tissue sample. The peaks for phenyl acetate and $o$-cresyl acetate were symmetrical and appeared at 16.12 and $16.63 \mathrm{~min}$, respectively.

Linearity of Calibration Curves. Due to the fact that the concentrations of phenol may be distributed over a large range in the fish tissue samples, two sets of five-point calibration curves were prepared over 2 concentration ranges. The linearity of the calibration curves were expressed by the coefficients of determination $\left(r^{2}\right)$, which were 0.9962 and 0.9978 for the ranges $10-100 \mu \mathrm{g} / \mathrm{kg}$ and $100-600 \mu \mathrm{g} / \mathrm{kg}$, respectively, indicating a reasonably good linearity. The regression equations for the low and high concentration ranges were $y=0.0023 x+0.0028$ and $y=0.0020 x+0.038$, respectively, where $y$ is the ratio of the peak area for phenol to the peak area for $o$-cresol and $x$ is phenol concentration.

MDL, LOQ, Accuracy, and Precision. The MDL and LOQ were estimated as $8.0 \mu \mathrm{g} / \mathrm{kg}$ and $26 \mu \mathrm{g} / \mathrm{kg}$, respectively

Table 1. GC-MS conditions

\begin{tabular}{|c|c|c|}
\hline & Parameter & Option or condition \\
\hline \multirow{7}{*}{$\begin{array}{l}\text { GC (7890A; } \\
\text { Agilent Technologies) }\end{array}$} & Column & Agilent DB-WAX $(30 \mathrm{~m} \times 0.25 \mathrm{~mm} \times 0.25 \mu \mathrm{m})$ \\
\hline & Oven program & $\begin{array}{c}40{ }^{\circ} \mathrm{C} \text {, held for } 3 \mathrm{~min} \rightarrow \text { raised to } 150^{\circ} \mathrm{C}\left(10^{\circ} \mathrm{C} / \mathrm{min}\right) \rightarrow \text { raised to } \\
230^{\circ} \mathrm{C}\left(25^{\circ} \mathrm{C} / \mathrm{min}\right) \text {, held at } 230^{\circ} \mathrm{C} \text { for } 20 \mathrm{~min}\end{array}$ \\
\hline & Inlet port temperature & $240^{\circ} \mathrm{C}$ \\
\hline & Injection mode & Splitless mode \\
\hline & Carrier gas (flow rate) & $\mathrm{He}(1 \mathrm{~mL} / \mathrm{min})$ \\
\hline & Injection volume & $1 \mu \mathrm{L}$ \\
\hline & Transfer line temperature & $240^{\circ} \mathrm{C}$ \\
\hline \multirow{4}{*}{$\begin{array}{l}\text { MS ( } 5975 \mathrm{C} \text {; } \\
\text { Agilent Technologies) }\end{array}$} & EI mode & $70 \mathrm{eV}$ \\
\hline & Ion source temperature & $230{ }^{\circ} \mathrm{C}$ \\
\hline & Quadrupole temperature & $150^{\circ} \mathrm{C}$ \\
\hline & Selected ions $(m / z)$ & $\begin{array}{c}66,94 \\
107,108\end{array}$ \\
\hline
\end{tabular}




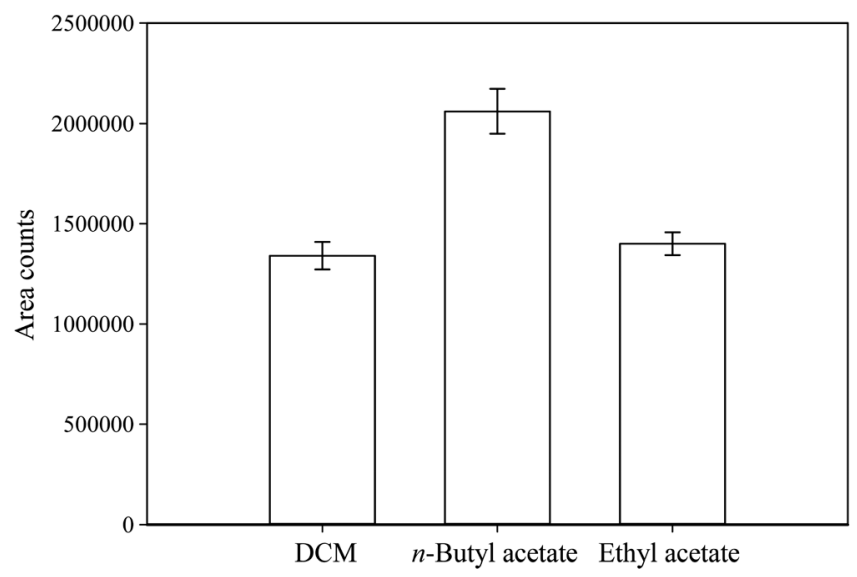

Figure 2. Selection of a suitable solvent for extracting phenyl acetate from the derivatization reaction mixture. $n$-Butyl acetate showed the highest extraction efficiency and was chosen as an extraction solvent $(n=3)$
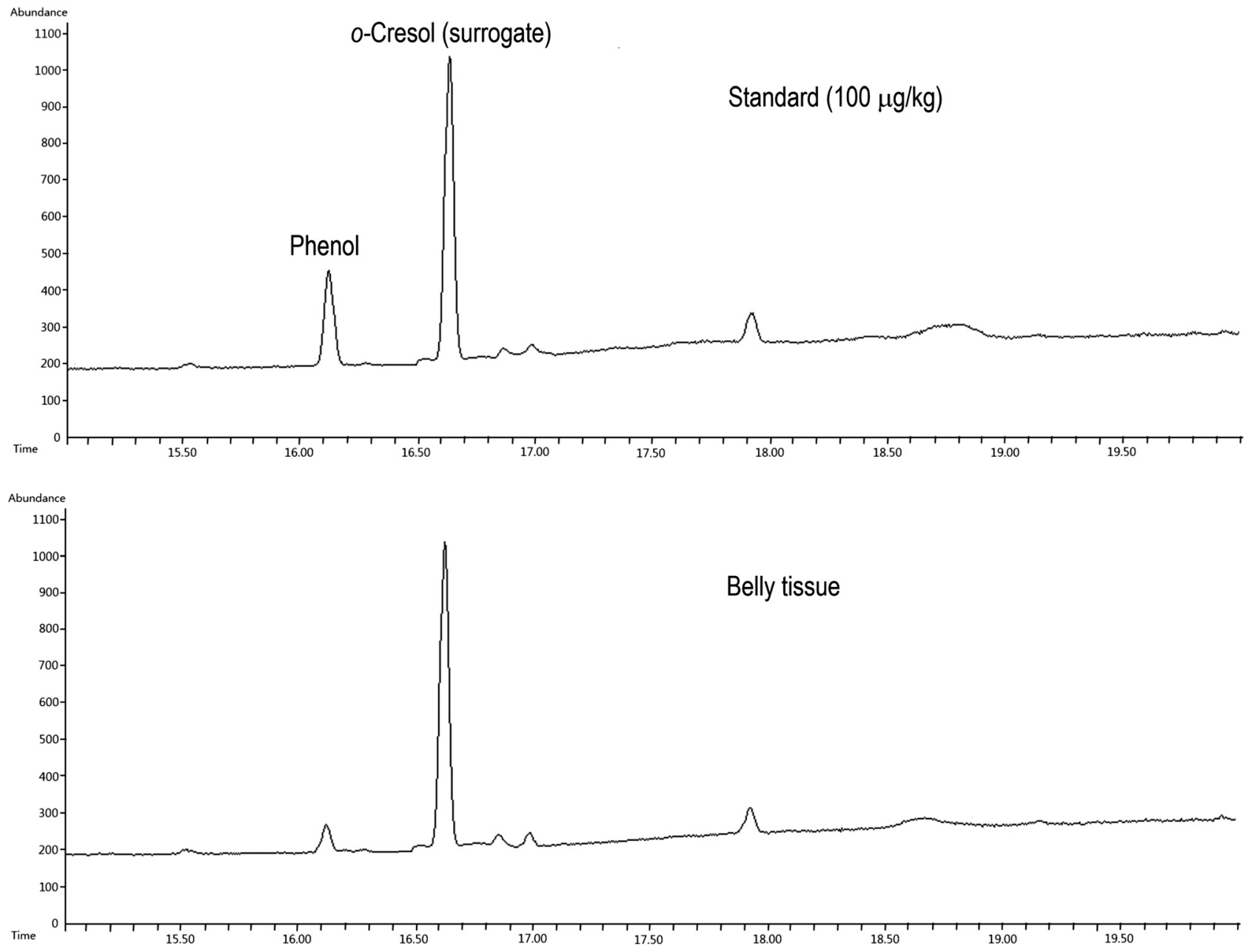

Figure 3. Chromatograms of a $100 \mu \mathrm{g} / \mathrm{kg}$ phenol standard (top) and a belly sample (bottom). $o$-Cresol was used as a surrogate

(Table 2). The LOQ was lower than the value $(100 \mu \mathrm{g} / \mathrm{kg})$, obtained for mackerel, which was analyzed for phenol itself by GC-MS without a derivatization step [13]. The recoveries for $10 \mu \mathrm{g} / \mathrm{kg}$ and $100 \mu \mathrm{g} / \mathrm{kg}$ concentrations were $98.2 \%$ and $96.3 \%$, respectively, much higher than those $(82.2-86.8 \%)$ for fortified 250-1000 $\mu \mathrm{g} / \mathrm{kg}$ samples of mackerel [13]. The repeatability, which was represented by relative standard deviations for $10 \mu \mathrm{g} / \mathrm{kg}$ and $100 \mu \mathrm{g} / \mathrm{kg}$, was $6.24 \%$ and $6.14 \%$, respectively (Table 2 ), indicating a reasonably good accuracy and precision.

Phenol Concentrations in Fish Tissues. In the belly samples, phenol was found at $47.3( \pm 9.7) \mu \mathrm{g} / \mathrm{kg}(n=4)$ in crucian carp alone, whereas it was found below the MDL in dace and striped mullet. The concentrations of phenol were $26.5( \pm 25.5)$, below the LOQ, and $100( \pm 34) \mu \mathrm{g} / \mathrm{kg}$ in the gill samples of dace, striped mullet, and crucian carp, respectively. Phenol was found at $216( \pm 44), 387( \pm 147)$, and $121( \pm 30) \mu \mathrm{g} / \mathrm{kg}$

Table 2. Method validation results

\begin{tabular}{lccccccc}
\hline Parameter & MDL & LOQ & \multicolumn{2}{c}{ Recovery (\%) } & & \multicolumn{2}{c}{ RSD (\%) } \\
& $(\mu \mathrm{g} / \mathrm{kg})$ & $(\mu \mathrm{g} / \mathrm{kg})$ & $\begin{array}{c}10 \\
\mu \mathrm{g} / \mathrm{kg}\end{array}$ & $\begin{array}{c}100 \\
\mu \mathrm{g} / \mathrm{kg}\end{array}$ & & $\begin{array}{c}10 \\
\mu \mathrm{g} / \mathrm{kg}\end{array}$ & $\begin{array}{c}100 \\
\mu \mathrm{g} / \mathrm{kg}\end{array}$ \\
\hline Value & 8.0 & 26 & 98.2 & 96.3 & & 6.42 & 6.14 \\
\hline
\end{tabular}


in the renal tubules of dace, striped mullet, and crucian carp, respectively, indicating that phenol is detected at the highest concentration in the renal tubules.

\section{Conclusion}

In this paper, an analytical method for the quantitative determination of phenol in fish tissues using solvent extraction and derivatization to a more volatile derivative was developed. This method was demonstrated to have a lower detection limit than previous methods, satisfactory linearity of the calibration curves, high accuracy, and good intraday precision. This method is also applicable to other biological tissues, such as meat, sediments, and soil. Further, the application of this method to other phenol analogs, such as alkylphenols, bisphenols, and chlorinated phenols, can be considered.

\section{References}

1. Bruce, R. M.; Santodonato, J.; Neal, M. W. Toxicol. Ind. Health 1987, 3, 535.
2. US EPA Toxicological Review of Phenol (CAS No. 108-95-2) Integrated Risk Information System (IRIS), National Center for Environmenta Assessment, Office of Research and Development, Washington, DC, USA, 2002.

3. ATSDRToxicological Profile for PhenolPublic Health Service, U.S. Department of Health Services, Atlanta, GA, USA, 2008.

4. Razani, H.; Nanba, K.; Murachi, S. B. Jpn. Soc. Sci. Fish. 1986, 52, 1547

5. Saha, N. C.; Bhunia, F.; Kaviraj, A. B. Environ. Contam. Tox. 1999 63, 195

6. Ballesteros, E.; Gallego, M.; Valcarcel, M. J. Chromatogr. 1990, 518, 59.

7. Llompart, M.; Lourido, M.; Landín, P.; García-Jares, C.; Cela, R. J. Chromatogr. A 2002, 963, 137.

27

8. Bagheri, H.; Saber, A.; Mousavi, S. R. J. Chromatogr. A 2004, 1046,

9. Faraji, H. J. Chromatogr. A 2005, 1087, 283.

10. Park, S.; Kim, Y.; Jung, S.; Kim, H. Kor. J. Environ. Agric. 2017, 36, 63.

11. Stahl, L. L.; Snyder, B. D.; Olsen, A. R.; Pitt, J. L. Environ. Monit. Assess. 2009, 150, 3

12. US EPA Method 1625C Semivolatile Organic Compounds by Isotope Dilution GCMS Office of Science and Technology Engineering and Analysis Division, Washington, DC, USA, 1989.

13. Kang, Y. W.; Ahn, J. E.; Suh, J. H.; Park, S. H.; Yoon, H. J. J. Food Hyg. Safety 2014, 29, 312 .

14. US EPA Definition and Procedure for the Determination of the Method Detection Limit, Revision 2 Office of Water, Washington, DC, USA, 2016. 